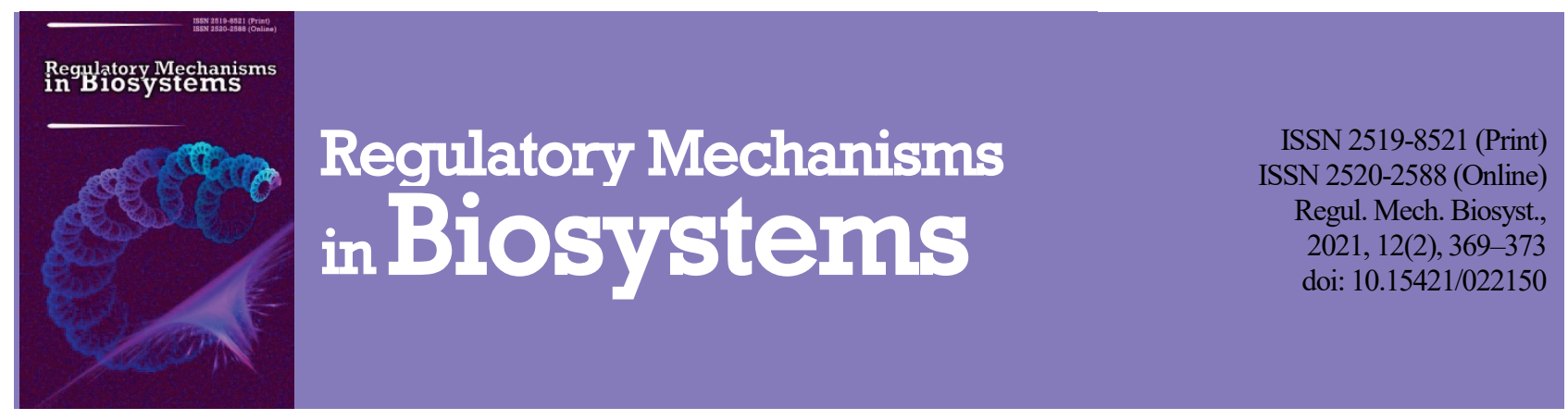

\title{
Influence of temperature on sporulation of Eimeria arloingi and Eimeria perforans oocysts
}

\author{
O. O. Boyko*, L. I. Shendryk*, V. S. Rudyk*, I. A. Volovyk*, I. A. Biben*, V. V. Brygadyrenko**** \\ *Dnipro State Agrarian and Economic University, Dnipro, Ukraine \\ **Oles Honchar Dnipro National University, Dnipro, Ukraine
}

Article info

Received 28.03.2021

Received in revised form 02.05.2021

Accepted 03.05.202

Dnipro State Agrarian and Economic

University, Sergiv Yefremov st., 25,

Dnipro, 49000, Ukraine.

Tel.: + 38-097-296-42-10.

E-mail:boikoalexandra1982@

gmail.com

Oles Honchar Dnipro National

University, Gagarin av., 72,

Dnipro, 49010, Ukraine.

Tel.: +38-050-93-90-788

E-mail:brigad@ua.fm

\begin{abstract}
Boyko, O. O., Shendryk, L. I., Rudyk, V. S., Volovyk, I. A., Biben, I. A., \& Brygadyrenko, V. V. (2021). Influence of temperature on sporulation of Eimeria arloingi and Eimeria perforans oocysts. Regulatory Mechanisms in Biosystems, 12(2), 369373. doi:10.15421/022150
\end{abstract}

Eimeriosis of farm animals is one of the most widespread parasitic diseases in the world. In the conditions of the steppe zone of Ukraine Eimeria perforans is more common in rabbits and E. arloingi in sheep and goats. Study of factors which influence the development of these protists on the soil surface is one of the major challenges for veterinarians working for large livestock companies and fighting against eimeriosis. Environmental temperature is able to change the speed of sporulation of oocysts Eimeria. Five values of temperature $\left(15,20,25,30\right.$, and $\left.35^{\circ} \mathrm{C}\right)$ were used in a laboratory experiment in vitro. At $15^{\circ} \mathrm{C}$, the process of sporulation of E. arloingi and E. perforans in $100 \%$ of cases ended on the eighth day. With increase in temperature to $35^{\circ} \mathrm{C}$, the duration of sporulation decreased to three days. When the temperature was $30{ }^{\circ} \mathrm{C}$ the completion of sporulation was observed in more than $50 \%$ of the oocysts of E. arloingi on the second day, and for E. perforans on the third day. High-speed sporulation at elevated temperatures under conditions of global warming can result in the increasing spread of eimeriosis among wild and domestic animals.

Keywords: sporulation; oocysts; eimeriosis; oocysts; sporozoites; sporocysts; sheep and goats; rabbits.

\section{Introduction}

The genus Eimeria belongs to the protists of the Apicomplexa type and includes more than 1,700 species, they store their genetic information in the chromosomes contained in the nucleus. They feed mainly by pinocytosis (absorption of nutrients from the extracellular space by invagination of the membrane) or phagocytosis (surrounding solid particles by the cytoplasmic membrane and introducing them into the cell), and metabolic products are excreted by diffusion through the cell membrane.

Most often, these protists parasitize in the intestinal epithelium. Their life cycle is closely related to the physiological characteristics of vertebrates - their hosts. The life cycle of Eimeria includes three types of reproduction: sporogony, meronia and gametogony. It is the elucidation of the peculiarities of these methods of reproduction that helps to develop various methods of controlling the eimeria of wild and domestic vertebrates (Taylor et al., 2007).

Eimeriosis is usually an acute invasion of domestic and wild mammals, birds, which develops against the background of reduced immune protection of animals, is characterized by increased susceptibility to infectious and invasive diseases, and is complicated by pathogenic microorganisms. Clinical signs include diarrhea (sometimes bloody), fever, loss of appetite, weight loss, exhaustion, and, in extreme cases, death. However, often this parasitosis has a subclinical course. Eimeriosis often causes enzootic diseases in rabbits, chickens, ducks, geese, turkeys, calves, lambs, goats, and pigs, causing significant economic damage to livestock, especially through deaths. And some species of Eimeria can cause the death of about $80-98 \%$ of young animals, other species - lag in growth and development, deteriorating quality of livestock products, reduced productivity, susceptibility of animals to secondary bacterial and viral infections. Additional economic losses also arise from the effort taken to care for and treat infected animals (Müller \& Hemphill, 2013; Fatoba \& Adeleke, 2018).
In general, for most farm animal species, the level of infection is high and the incidence of clinical manifestations of the disease is low; many high-risk animals may show clinical signs of eimeriosis. Most animals become infected with eimeriosis of varying severity at the age of 1-12 months. Animals over one year of age are usually resistant to these parasites, clinical manifestations are usually absent. Clinically healthy mature animals can be a source of infection for young, animals susceptible to Eimeria. Unsanitary conditions contribute to the growth of infection of farm animals. The disease occurs as a result of swallowing a large number of sporulated oocysts. The stress of weaning and transporting animals can provoke disease (Almeida et al., 2011; Andrushko \& Egorov, 2015; Tadesse \& Feyissa, 2016; Ekawasti et al., 2019).

Many researchers emphasize that mammals and birds are mostly sick in warm and humid periods of the year (depending on the climatic zone, these are different periods of the year). This is due to the fact that high humidity and heat create favourable conditions for the maturation and preservation in the environment of oocysts of Eimeria. However, seasonal fluctuations in the infestation of mammals and birds are clearly traced in farms where animals are kept in violation of breeding technology, in unsatisfactory veterinary and sanitary and zoohygienic conditions, with poor feeding (Ruiz et al., 2006; Sazmand et al., 2012; Wondimu et al., 2019).

In Ukraine, the level of eimeriosis in animals depends on many factors, including natural and climatic zones (Table 1). Veterinary support of farms is an integral part of the technological process. World veterinary science has developed and recommends the use of chemicals throughout the breeding period to prevent eimeriosis (Fasil, 2019; Franchuk-Kryva, 2019; Kachanova \& Pavlova, 2020; Yakovleva et al., 2021).

The highest intensity of invasion among the rabbit population was recorded in September (on average 800 oocysts/g of feces), among small ruminants, the peak was in February (on average, in goats, 1675, in sheep, 400 oocysts/g of feces). The lowest rates of invasion intensity among 
rabbits were observed in June (on average 460 oocysts/g of feces), and among small ruminants - in April (on average in goats, 825, in sheep, 62 oocysts/g of feces).

However, the system of anti-Eimeria measures on a number of Ukrainian farms continues to be ineffective. At present, the peculiarities of the epizootology and species composition of the causative agents of eimeriosis are not sufficiently studied, which is a barrier to the development of an effective system for combating Eimeria. The distribution range of different species of parasites of this genus remains insufficiently studied. New livestock farms of various forms of ownership have been created and continue to be created throughout Ukraine, and studies of effective measures to control eimeriosis remain relevant (Girkovyj, 2012; Bogach et al., 2015; Korjachkov, 2015; Franchuk, 2015). In this regard, it is important to study the duration of sporulation of oocysts of different species of Eimeria - parasites of birds and mammals to develop and improve a system of scientifically sound measures to control them.

Table 1

The spread of eimeriosis of farm animals in Ukraine

\begin{tabular}{|c|c|c|c|c|c|c|}
\hline $\begin{array}{c}\text { Natural } \\
\text { climatic zone }\end{array}$ & Region & Types of farms & Species & $\begin{array}{l}\text { Extensiveness } \\
\text { of invasion, } \%\end{array}$ & Intensity of invasion & Reference \\
\hline $\begin{array}{l}\text { Polissia } \\
\text { (Forest zone) }\end{array}$ & Zhytomyr & $\begin{array}{l}\text { rabbits } \\
\text { (2-6 months) }\end{array}$ & $\begin{array}{l}\text { E. stiedae, E. magna, } \\
\text { E. perforans }\end{array}$ & $\begin{array}{l}57.0-59.0 \\
\text { (Eimeria } \mathrm{spp} .)\end{array}$ & $\begin{array}{l}\text { 157-165 parasites in } 3 \text { drops of physiological solu- } \\
\text { tion (Eimeria spp.) }\end{array}$ & Dovgij et al. (2013) \\
\hline $\begin{array}{l}\text { Forest-Steppe } \\
\text { zone }\end{array}$ & $\begin{array}{l}\text { Vinnytsia } \\
\text { Kharkiv }\end{array}$ & $\begin{array}{l}\text { cattle } \\
\text { sheep }\end{array}$ & $\begin{array}{l}\text { Eimeria spp. } \\
\text { E. ninaekohl-jakimovae, } \\
\text { E. arloingi, } \\
\text { E. faurei }\end{array}$ & $\begin{array}{l}23.7 \\
65.4 \\
\text { (Eimeria spp.) }\end{array}$ & $\begin{array}{l}19.8 \pm 1.1 \text { oocysts } / 10 \text { fields of view of the microscope } \\
-\end{array}$ & $\begin{array}{l}\text { Skalchuk (2021) } \\
\text { Byrka et al. (2017) }\end{array}$ \\
\hline & Poltava & $\begin{array}{l}\text { rabbits } \\
\text { goats }\end{array}$ & $\begin{array}{l}\text { Eimeria } \text { spp. } \\
\text { Eimeria } \text { spp. }\end{array}$ & $\begin{array}{l}47.7 \\
22.4\end{array}$ & $\begin{array}{l}14.6 \text { oocysts/a field of view of the microscope } \\
73.7 \pm 26.8 \text { oocysts } / g \text { of feces }\end{array}$ & $\begin{array}{l}\text { Klymenko (2015) } \\
\text { Yevstafieva et al. (2020) }\end{array}$ \\
\hline Steppe zone & Odesa & rabbits & $\begin{array}{l}\text { E. stiedae, } \\
\text { E. magna, } \\
\text { E. media, } \\
\text { E. perforans, } \\
\text { E. intestinalis }\end{array}$ & $\begin{array}{l}33.8 \\
25.6 \\
22.0 \\
18.0 \\
0.6\end{array}$ & $\begin{array}{l}58.1 \pm 6124.9 \text { thousand of oocysts / } g \text { of feces } \\
\text { (Eimeria spp.) }\end{array}$ & Franchuk (2015) \\
\hline & South part & cattle & Eimeria spp. & 17.4 & $26.1 \pm 1.4$ oocysts $/ 10$ fields of view of the microscope & Skalchuk (2021) \\
\hline & North part & cattle & Eimeria spp. & 24.4 & $28.5 \pm 1.2$ oocysts $/ 10$ fields of view of the microscope & \\
\hline & Crimea & rabbits & $\begin{array}{l}\text { E. stiedae } \\
\text { E. perforans } \\
\text { E. magna } \\
\text { E. intestinalis }\end{array}$ & $\begin{array}{l}21.5 \\
44.5 \\
13.6 \\
20.4\end{array}$ & $\begin{array}{l}\text { 5-2540 oocysts / } 20 \text { fields of view of the microscope } \\
\text { (Eimeria spp.) }\end{array}$ & Trofimov et al. (2013) \\
\hline & $\begin{array}{l}\text { Dnipropetrovsk } \\
\text { Zaporizhzhia }\end{array}$ & $\begin{array}{l}\text { rabbits } \\
\text { rabbits }\end{array}$ & $\begin{array}{l}\text { Eimeria } \text { spp. } \\
\text { Eimeria spp. }\end{array}$ & $\begin{array}{l}89.2-83.9 \\
77.1-71.4\end{array}$ & $\begin{array}{l}3958-4456 \text { oocysts } / g \text { of feces } \\
751-776\end{array}$ & Prus et al. (2021) \\
\hline
\end{tabular}

\section{Material and methods}

The studies were carried out in the laboratory of the Department of Parasitology and Veterinary and Sanitary Expertise of the Dnipro State Agrarian and Economic University in 2021. Fecal samples were taken from ruminant ungulates and rabbits naturally infected with Eimeria kept in the Educational, Research and Production, Clinical and Diagnostic Center of the Faculty of Veterinary Medicine of the Dnipro State Agrarian and Economic University. Examination of feces for the presence of Eimeria spp. carried out by the McMaster method.

In the climatic conditions of the steppe zone of Ukraine, several species of Eimeria were found in ruminants and rabbits. In goats, E. arloing oocysts were found in $73 \%$ of cases (extensiveness of invasion), E. ninaekohlyakimovae $-11 \%$, E. parva $-12 \%$, . alijevi $-4 \%$. In sheep, E. ninaekohlyakimovae $-85 \%$ and $E$. parva $-15 \%$ were registered. In rabbits, two types of eimeria were found: in $78 \%-E$. perforans, in $28 \%-$ E. stiedae.

As a result of the research, the types were determined according to the main characteristics of the Eimeria of Ukraine:

-E. arloingi - oocysts of round, ellipsoidal or oval shape, 20-31 $\times$ $16-23 \mu \mathrm{m}$; the oocyst wall consists of two layers; there is a micropyle, and the micropolar cap is barely noticeable;

-E. ninaekohlyakimovae - round or ellipsoidal oocysts, 16.5-27.5 × 13.3-23.1 $\mu \mathrm{m}$; the polar cap and micropyle are absent;

-E. parva - oval or ellipsoidal oocysts, 9.9-18.7 × 7.7-13.3 $\mu \mathrm{m}$; the wall of the oocysts is smooth, pale yellow, there is no micropyle;

- E. perforans - oocysts of ellipsoidal or oval shape, $13-31 \times 11-$ $20 \mu \mathrm{m}$, transparent or with a pink tint, with a smooth shell, no micropyle;

- E. stiedae - oocysts are oval or ellipsoidal, $31-42 \times 17-25 \mu \mathrm{m}$ in shape, have a smooth yellow-brown shell; there is a micropyle at the narrowed pole.

Non-sporulated oocysts contain germ mass. After culture, the sporulated oocysts contain 4 sporocysts. Each sporocyst contains two sporozoites. For the experiment, we used five temperature regimes $(15,20,25$, 30 and $35^{\circ} \mathrm{C}$ ) of a TCO-80 MICROmed thermostat. Samples of excrement from goats and rabbits ( $2 \mathrm{~g}$ each) were put separately in beakers $(\mathrm{n}=$
3) and placed in a thermostat. Oocyst sporulation was monitored every day. The percentage of sporulated and non-sporulated oocysts in each sample was calculated. Eimeria arloingi (Marotel, 1905) Martin, 1909 oocytsts and E. perforans (Leuckart, 1879) Sluiter and Swellengrebel, 1912 oocysts were used in the experiment. Results are presented as arithmetic mean \pm standard error $(\mathrm{x} \pm \mathrm{SE})$.

\section{Results}

According to the research results, sporulation in E. perforans oocysts occurred more slowly than in E. arloingi (Table 2). The longest sporulation process was recorded at $15^{\circ} \mathrm{C}$ - eight days; more than $50 \%$ of sporulated oocysts were identified on the fifth day of the experiment. At $15^{\circ} \mathrm{C}$ on the seventh day of the experiment, more than $90 \%$ of sporulated oocysts were recorded.

At $20^{\circ} \mathrm{C}$, sporulation of $E$. perforans and $E$. arloingi oocysts ended on the sixth day of the experiment. However, only on the fourth day was there a noticeable increase in the number of sporulated oocysts (more than $50 \%$ ). At a temperature of $25{ }^{\circ} \mathrm{C}$, sporulation of both studied types of Eimeria was $100 \%$ completed on the fifth day of the experiment. More than $50 \%$ of sporulated oocysts were also recorded on the fourth day of the experiment, compared with a temperature of $20^{\circ} \mathrm{C}$.

At a temperature of $30{ }^{\circ} \mathrm{C}$, more than $50 \%$ of sporulated oocysts were found already on the second day of the experiment in E. arloingi and on the third day in $E$. perforans. $100 \%$ of sporulated $E$. perforans and E. arloingi oocysts were determined on the fourth day of the experiment.

At a temperature of $35^{\circ} \mathrm{C}, 100 \%$ sporulation of the oocysts of the studied Eimeria species was already observed on the third day of the experiment; on the second day, more than $50 \%$ of the sporulated oocysts of the two studied species were found.

Thus, on average, sporulation of oocysts occurs starting from the second day of the experiment, and the peak of sporulation in the majority of oocysts falls on the third or fourth day. The most favourable conditions for sporulation of Eimeria oocysts were recorded at $35^{\circ} \mathrm{C}$ (E. perforans $62.4 \%$ of sporulated oocysts on the second day of the study; E. arloingi$71.9 \%)$. 
Table 2

Sporulation rate (\%) of E. arloingi and E. perforans oocysts depending on temperature $(\mathrm{x} \pm \mathrm{SE}, \mathrm{n}=3)$

\begin{tabular}{|c|c|c|c|c|c|c|c|c|c|}
\hline \multirow{2}{*}{ Species } & \multirow{2}{*}{$\begin{array}{c}\text { Temperature, } \\
\text { C }\end{array}$} & \multicolumn{8}{|c|}{ Durations, days } \\
\hline & & 1 & 2 & 3 & 4 & 5 & 6 & 7 & 8 \\
\hline \multirow{5}{*}{ E.perforans } & 15 & 0 & $2.78 \pm 0.11$ & $14.77 \pm 0.19$ & $32.98 \pm 0.82$ & $59.41 \pm 1.18$ & $84.26 \pm 0.46$ & $94.28 \pm 0.39$ & $100.00 \pm 0.00$ \\
\hline & 20 & 0 & $10.55 \pm 1.18$ & $23.40 \pm 0.91$ & $57.88 \pm 1.05$ & $87.46 \pm 0.71$ & $100.00 \pm 0.00$ & - & - \\
\hline & 25 & 0 & $17.40 \pm 0.52$ & $34.78 \pm 2.46$ & $77.30 \pm 0.40$ & $100.00 \pm 0.00$ & - & - & - \\
\hline & 30 & 0 & $43.84 \pm 0.32$ & $82.84 \pm 0.59$ & $100.00 \pm 0.00$ & - & - & - & - \\
\hline & 35 & 0 & $62.44 \pm 0.96$ & $100.00 \pm 0.00$ & - & - & - & - & - \\
\hline \multirow{5}{*}{ E. arloingi } & 15 & 0 & $6.73 \pm 0.59$ & $17.10 \pm 0.85$ & $38.66 \pm 1.20$ & $63.28 \pm 0.70$ & $89.24 \pm 1.05$ & $97.05 \pm 0.58$ & $100.00 \pm 0.00$ \\
\hline & 20 & 0 & $14.69 \pm 1.09$ & $33.55 \pm 0.92$ & $64.54 \pm 1.51$ & $93.58 \pm 1.04$ & $100.00 \pm 0.00$ & - & - \\
\hline & 25 & 0 & $22.09 \pm 0.59$ & $43.60 \pm 0.72$ & $83.91 \pm 1.52$ & $100.00 \pm 0.00$ & - & - & - \\
\hline & 30 & 0 & $53.84 \pm 1.02$ & $88.89 \pm 0.71$ & $100.00 \pm 0.00$ & - & - & - & - \\
\hline & 35 & 0 & $71.92 \pm 1.03$ & $100.00 \pm 0.00$ & - & - & - & - & - \\
\hline
\end{tabular}

Discussion

Coccidiosis (and one of its forms - eimeriosis) is widespread throughout the world. Some authors study the influence of various factors on the viability of oocysts and the duration of their sporulation. Waldenstedt et al. (2001) determined the effect of litter moisture on sporulation of E. maxima oocysts. The experiment was carried out using litter of different moisture content: $16 \%, 42 \%$, and $62 \% ;$ E. maxima sporulation occurs most intensively at the lowest litter moisture content (16\%), and in conditions with the highest moisture content (62\%), this process is inhibited.

The importance of bedding material for the survival of Eimeria oocysts is highlighted by Soliman et al. (2018). They added superphosphates, meta-bisulfides and charcoal additives to the bedding material. All of these additives have been shown to be effective in inhibiting sporulation and reducing the viability of Eimeria oocysts. The regular use of these substances in poultry farms can become one of the therapeutic and preventive measures for reducing the survival rate and inhibiting the maturation of oocysts of different species of the genus Eimeria.

There is a lot of data on the effect of plant extracts on the oocysts of these parasitic protozoa. In our earlier published work, experiments on the effect of essential oils on the sporulation of $E$. magna (Perard, 1925), rabbit parasites, are described. The essential oils of 14 plant species (Piper cubeba, Cananga odorata, Pelargonium graveolens, Citrus sinensis, Eucalyptus globulus, Lavandula angustifolia, Picea abies, Citrus paradisi, Pterocarpus santalinus, Abies sibirica, Juniperus communis, Melaleuca alternifolia, and Cyzygium aromaticum) were studied. The essential oil of Cinnamomum verum had the greatest effect on the sporulation of $E$. mag$n a$ oocysts. When exposed to an aqueous emulsion of the essential oil of this plant for 72 hours, $100 \%$ death of oocysts was recorded. Syzygium aromaticum oil was less effective. Under its influence, about $54 \%$ the death of partially sporulated oocysts was observed. It was also found that essential oils of $P$. abies, C. paradisi, P. santalinus, A. sibirica, J. communis, and $M$. alternifolia can delay the sporulation of $E$. magna oocysts (Boyko et al., 2021).

Gadelhaq et al. (2018) investigated the ability of two herbal extracts, Allium sativum and Moringa olifiera, to suppress or disrupt the sporulation of Eimeria oocysts, a chicken parasite. However, no positive result was observed. Arfan Zaman et al. (2015) in vitro evaluated the effect of Curcuma longa leaves, Artemisia absinthium seeds, and Saussurea lappa roots on the sporulation of Eimeria tenella: the extract of $C$. longa had the highest inhibitory effect.

Fatemi et al. (2015) compared the effect of different Artemisia annua extracts on the sporulation rate of E. acervulina, E. necatrix, and E. tenella oocysts. Ethanol $(96 \%)$ and petroleum extracts of $A$. апnиa inhibit the sporulation of oocysts of the studied Eimeria species at concentrations of 2:1000 and 5:1000. In this case, the proportions of inhibition of oocysts compared with the control were $31 \%$ at a concentration of 5:1000 and $29 \%-2: 1000$ for petroleum extract. Ethanol extract $(96 \%)$ had a stronger effect: $34 \%$ and $46 \%$ inhibition of sporocyst development for concentrations of 5:1000 and 2:1000, respectively.

The effect of temperature on the sporulation of parasitic protozoan oocysts is described by many authors around the world. According to Pyziel \& Demiaszkiewicz (2015), the efficiency of sporulation of E. bovis oocysts (Zublin, 1908), a parasite of the European bison Bison bonasus (Linnaeus, 1758), increases with increasing temperature; sporulation of oocysts of this Eimeria species at a temperature of $18{ }^{\circ} \mathrm{C}$ and the addition of a solution of potassium dichromate $\left(\mathrm{K}_{2} \mathrm{Cr}_{2} \mathrm{O}_{7}\right)$ occurs within six days. An increase in temperature by $5{ }^{\circ} \mathrm{C}$ under the same conditions leads to a reduction in the maturation time of oocysts by two days. At a temperature of $28^{\circ} \mathrm{C}$ and the addition of a $\mathrm{K}_{2} \mathrm{Cr}_{2} \mathrm{O}_{7}$ solution, E. bovis oocysts complete the sporulation process already on the second day. A similar experiment was carried out by these authors also in sterilized water: the results were very different; sporulation was much slower. At a temperature of $23{ }^{\circ} \mathrm{C}$ without adding a $\mathrm{K}_{2} \mathrm{Cr}_{2} \mathrm{O}_{7}$ solution, this process ended 9 days later, that is, on the 13th day. At a temperature of $3-5{ }^{\circ} \mathrm{C}$ in sterilized water, this process was completed only after 16 weeks. We have obtained similar results for $E$. perforans and $E$. arloingi. With an increase in temperature, a decrease in the duration of oocyst sporulation was recorded. However, the time spent on this process under the same temperature conditions was different for E. bovis and E. perforans, as well as for E. arloingi. At $15{ }^{\circ} \mathrm{C}$, the duration of sporulation of $E$. perforans and $E$. arloingi was much shorter (100\% in 8 days) than E. bovis, the process of sporulation of which was completed on the 13th day at a higher temperature $\left(23^{\circ} \mathrm{C}\right)$. Perhaps this difference is associated with the species characteristics of parasites, as well as with other microclimatic conditions, including humidity indicators.

Graat et al. (1994) report that the most important aspect of the development of E. acervulina is the timing of the onset of sporulation. Together with this, temperature is the most important regulator of this process. According to the results of the experiment, Graat et al. (1994) a temperature of $33{ }^{\circ} \mathrm{C}$ contributed to a much faster completion of the sporulation process than a temperature of $21^{\circ} \mathrm{C}$.

According to the results of other experiments (Marquardt et al., 1960), the temperature at the time of the onset of sporulation is also of great importance. In $50 \%$ of $E$. zurnii oocysts (parasites of cattle), the sporulation process began after 65 hours at $20^{\circ} \mathrm{C}$ and much faster - after 36 hours at $25{ }^{\circ} \mathrm{C}$. In this case, normal sporulation of $E$. zurnii oocysts occurs at a temperature of $8.0-32.5^{\circ} \mathrm{C}$. At temperatures below $12^{\circ} \mathrm{C}$, the sporulation time increases. But already a temperature of $35^{\circ} \mathrm{C}$ leads to morphological abnormal changes. The optimum temperature for sporulation of $E$. zurnii oocysts was about $30^{\circ} \mathrm{C}$. An experiment on the effect of temperature on the process of sporulation of oocysts was carried out on the same species of Eimeria (Marquardt, 1960). He showed that E. zurnii cannot sporulate at high temperatures. The first sign of high temperature damage to the oocysts of this Eimeria species is a decrease in the number of normally sporulating oocysts. Sporulation of E. zurnii is faster at $35^{\circ} \mathrm{C}$ than at lower temperatures $\left(25^{\circ} \mathrm{C}\right)$. At the same time, the number of normally sporulating oocysts is significantly reduced. According to Marquardt (1960), E. zurnii sporulation occurs in two stages. This is a preliminary segmentation (the process of which is shortened by exposure to high temperature), as well as the subsequent process of sporulation (segmentation itself), which stops in these temperature conditions.

Similar experiments were carried out by Schneiders et al. (2020). These authors point out that a subsequent increase in temperature may, on the contrary, slow down the process of oocyst development. According to their data, the viability of sporozoites declines when exposed in vitro for at least 60 minutes at a temperature of $55^{\circ} \mathrm{C}$, which is confirmed by their morphological changes. The development of merozoites is significantly inhibited when the temperature rises $2{ }^{\circ} \mathrm{C}$ higher than the optimal in vitro incubation temperature. 
Temperature also affects the number of oocysts that are released into the environment. According to Ruiz et al. (2006), the highest intensity of eimerious invasion in goats from semi-arid zones was recorded in the hot season. Eight species of Eimeria (E. ninakohlyakimovae, E. arloingi, E. alijevi, E. caprina, E. christenseni, E. jolchijevi, E. caprovina, E. hirci) have been recorded in goats of the arid desert zone of Gran Canaria (Spain). Ruiz et al. (2006) found that the oocyst shedding rate of the detected Eimeria species was related to herd size as well as the prevailing climatic conditions in the area.

The data obtained by us can be used in the future to improve the rules for carrying out anti-eimeriosis measures for specific species of host animals in various climatic zones of the world. Global climatic changes are already increasing the intensity of the spread of many parasitic organisms (Makaida et al., 2021), and in the future the spread of eimeriosis may intensify due to the acceleration of the formation of their sporozoites in the environment. A decrease in the time from the moment of excretion of feces into the environment until the moment when they can effectively infect the next animal, by one or two days, can dramatically increase the prevalence of eimeriosis under the conditions of using various technologies for raising farm animals (Gutyj et al., 2019).

\section{Conclusion}

One of the main factors that influence the process of sporulation of eimerian oocysts is the temperature of the environment. Under in vitro conditions, with a decrease in temperature to $15{ }^{\circ} \mathrm{C}$, sporulation in E. perforans (parasites of rabbits) and $E$. arloingi (parasites of small ruminants) slowed down to 8 days. At a temperature of $35^{\circ} \mathrm{C}$, sporulation of oocysts of the studied species of parasitic protozoa ended on the third day in an in vitro experiment. These data can be used in the future when planning preventive measures in the fight against eimeriosis of farm animals to reduce the use of chemically synthesized disinfectants, in order to reduce the toxic load on agroecosystems, as well as on natural ecosystems.

\section{References}

Andrushko, E. S., \& Egorov, S. V. (2015). Epizootological monitoring of eimeriosis in young cattle in agricultural farms of Ivanovo region and contiguous areas. Russian Journal of Parasitology, 2, 27-31

Arfan Zaman, M., Iqbal, Z., Abbas, R. Z., \& Ehtisham-ul-Haque, S. (2015). In vitro efficacy of herbal extracts against Eimeria tenella. International Joumal of Agriculture and Biology, 17(4), 848-850

Bogach, M. V., Bogach, T. V., Bezdetko, L. J., \& Bondarenko, L. V. (2015). Ocinka efektyvnosti Toldu i Bajkoksu ta jih vplyv na biohimichni pokaznyky syrovatky krovi ovec za ejmerioznoji invaziji [Evaluation of the effectiveness of Tolcoccid and Baikoks and their effect on the biochemical parameters of sheep serum in Eimeria invasion]. Bulletin of Sumy National Agrarian University, Series of Veterinary Medicine, 7, 143-146 (in Ukrainian).

Boyko, O., Shendryk, L., Shaban, O., \& Brygadyrenko, V. (2021). Influence of essential oils on sporulation of Eimeria magna oocysts. Annals of Parasitology, 67(1), 11-17.

Byrka, V. I., Mazannyj, O. V., \& Nikiforova, O. V. (2017). Ejmeriozno-tryhurozna invazija ovec (poshyrennja, projav ta likuvannja) [Eimeriosis-trichurosis invasion of sheep (spread, onset and treatment)]. Problems of Zooengineering and Veterinary Medicine, 34(2), 282-287 (in Ukrainian).

Dovgij, J. J., Kushnirova, G. A., \& Dovgij, M. J. (2013). Ejmeriozy hutrovyh zviriv i domashnih ptahiv [Eimeriosis of fur animals and poultry]. Veterynama Medycyna, 97, 378-379 (in Ukrainian).

Fatemi, A., Razavi, S. M., Asasi, K., \& Torabi Goudarzi, M. (2015). Effects of Artemisia anmua extracts on sporulation of Eimeria oocysts. Parasitology Research, 114(3), 1207-1211.

Fatoba, A. J., \& Adeleke, M. A. (2018). Diagnosis and control of chicken coccidiosis: A recent update. Journal of Parasitic Diseases, 42(4), 483-493.

Franchuk, L. O. (2015). Ejmerioz kroliv (poshyrennja, patogenez, likuvannja) [Eimeriosis of rabbits (spread, pathogenesis, treatment)]. Nacionalnyj Universytet Bioresursiv i Pryrodokorystuvannja Ukrajiny, Kyiv (in Ukrainian).

Gadelhaq, S. M., Arafa, W. M., \& Abolhadid, S. M. (2018). In vitro activity of natural and chemical products on sporulation of Eimeria species oocysts of chickens. Veterinary Parasitology, 251, 12-16.

Girkovyj, A. J. (2012). Invazovanist' kurej zbudnykamy ejmeriozu v gospodarstvah L'vivs'koji oblasti [Invasion of chickens by eimeriosis pathogens in farms of L'viv region]. Naukovo-Tehnichnyj Bjuleten Instytutu Biologiji Tvaryn ta
Derzhavnogo Naukovo-Doslidnogo Kontrol'nogo Instytutu Vetpreparativ ta Kormovyh Dobavok, 13, 198-200 (in Ukrainian).

Graat, E. A. M., Henken, A. M., Ploeger, H. W., Noordhuizen, J. P. T. M., \& Vertommen, M. H. (1994). Rate and course of sporulation of oocyst of Eimeria acervulina under different environmental conditions. Parasitology, 108, 497-502.

Gutyj, B., Stybel, V., Hariv, I., Maksymovych, I., Buczek, K., Staniec, M., Milczak, A., Bushueva, I., Kulish, S., Shcherbyna, R., \& Samura, T. (2019). Influence of amprolinsile and brovitacoccid on the protein synthesizing function of the liver and enzyme activity in turkey blood serum during Eimeria invasion. Research Joumal of Pharmaceutical, Biological and Chemical Sciences, 10(2), 723-729.

Kachanova, E. O., \& Pavlova, E. V. (2020). Efficacy of the coadministration of coccidiocide and prebiotic to broiler chickens infected with Eimeria tenella oocysts. IOP Conference Series: Earth and Environmental Science, 548, 042009.

Ketema, E., \& Fasil, N. (2019). Study on prevalence and associated risk factors of poultry coccidiosis in and around alage at vet college, Southwestern Ethiopia. Joumal of Dairy and Veterinary Sciences, 11(1), 555805 .

Klymenko, O. S. (2015). Poshyrennja parazytoziv kroliv u pryvatnyh gospodarstvah Poltavs'koji oblasti [Distribution of rabbit parasitosis in private farms of Poltava region]. Visnyk Poltavs'koji Derzhavnoji Agrarnoji Akademiji, 1-2, 109-112 (in Ukrainian).

Korjachkov, V. A. (2015). Ejmerioz kroliv ta nutrij (poshyrennja, diagnostyka ta zahody borot'by) [Eimeriosis of rabbits and coypu (distribution, diagnosis and control measures)]. Lvivs'kyj Nacional'nyj Universytet Veterynarnoji Medycyny ta Biotehnologij imeni S. Z. Gzhyckogo, Lviv (in Ukrainian).

Makaida, M. V., Pakhomov, O. Y., \& Brygadyrenko, V. V. (2021). Effect of increased ambient temperature on seasonal generation number in Lucilia sericata (Diptera, Calliphoridae). Folia Oecologica, 48(2), 191-198.

Marquardt, W. C. (1960). Effect of high temperature on sporulation of Eimeria zurnii. Experimental Parasitology, 10(1), 58-65.

Marquardt, W. C., Senger, C. M., \& Seghetti, L. (1960). The effect of physical and chemical agents on the oocyst of Eimeria zurnii (Protozoa, Coccidia). The Journal of Protozoology, 7(2), 186-189.

Müller, J., \& Hemphill, A. (2013). In vitro culture systems for the study of apicomplexan parasites in farm animals. International Journal for Parasitology, 43(2), $115-124$.

Prus, M. P., Duda, J. V., \& Korejba, L. V. (2021). Invazovanist' ejmeriozom kroliv u domogospodarstvah Ukrajiny zalezhno vid pryrodno-klimatychnoji zony [Invasion with eimeriosis of rabbits in Ukrainian households depending on the natural and climatic zone]. In: Klimatychni Zminy ta Sil's'ke Gospodarstvo, Vyklyky dlia Agrarnoji Nauky ta Osvity. VFPO, Kyiv. Pp. 26-30 (in Ukrainian).

Pyziel, A. M., \& Demiaszkiewicz, A. W. (2015). Observations on sporulation of Eimeria bovis (Apicomplexa: Eimeriidae) from the European bison Bison bonasus: Effect of temperature and potassium dichromate solution. Folia Parasitologica, 62(1), 20

Ruiz, A., González, J. F., Rodríguez, E., Martín, S., Hemández, Y. I., Almeida, R., \& Molina, J. M. (2006). Influence of climatic and management factors on Eimeria infections in goats from semi-arid zones. Joumal of Veterinary Medicine Series B, 53(8), 399-402.

Sazmand, A., Hamidinejat, H., Hekmatimoghaddam, S., Asadollahi, Z., \& Mirabdollahi, S. (2012). Eimeria infection in camels (Camelus dromedarius) in Yazd province, Central Iran. Tropical Biomedicine, 29(1), 77-80.

Schneiders, G. H., Foutz J. C., Fuller, A. L., Nelson, J., Rekaya, R., \& Aggrey, S. E. (2020). The effect of increased temperatures on viability, morphology, infectivity, and development of Eimeria tenella. Joumal of Parasitology, 106(3), 428.

Skalchuk, V. V. (2021). Ejmeriozno-kryptosporydiozna invazija teljat (poshyrennja, patogenez, likuvannja) [Eimeriosis-cryptosporidiosis of calves (spread, pathogenesis, treatment)]. Nacional'nyj Universytet Bioresursiv i Pryrodokorystuvannja Ukrajiny, Kyiv (in Ukrainian).

Soliman, E. S., Sallam, N. H., \& Abouelhassan, E. M. (2018). Effectiveness of poultry litter amendments on bacterial survival and Eimeria oocyst sporulation. Veterinary World, 11(8), 1064-1073.

Tadesse, C., \& Feyissa, B. D. (2016). Poultry coccidiosis: Prevalence and associated risk factors in extensive and intensive farming systems in Jimma Town, Jimma, Ethiopia. Journal of Veterinary Medicine and Animal Health, 8(12), 223-227.

Taylor, M. A., Catchpole, J., Marshall, J., Marshall, R. N., \& Hoeben, D. (2003). Histopathological observations on the activity of diclazuril $\left(V^{2} \operatorname{coxan}^{\mathrm{B}}\right)$ against the endogenous stages of Eimeria crandallis in sheep. Veterinary Parasitology, 116(4), 305-314.

Trofimov, M. M., Onishhenko, N. G., \& Pasunkina, M. O. (2013). Epizootologichni osoblyvosti ejmeriozu kroliv u gospodarstvah AR Krym [Epizootological features of rabbit eimeriosis in farms of the Autonomous Republic of Crimea]. Veterynarna Medycyna, 97, 407-409 (in Ukrainian).

Waldenstedt, L., Elwinger, K., Lundén, A., Thebo, P., \& Uggla, A. (2001). Sporulation of Eimeria maxima oocysts in litter with different moisture contents. Poultry Science, 80(10), 1412-1415.

Wondimu, A., Mesfin, E., \& Bayu, Y. (2019). Prevalence of poultry coccidiosis and associated risk factors in intensive farming system of Gondar Town, Ethiopia. Veterinary Medicine International, 2019(9), 1-6. 
Yakovleva, I. N., Yakovleva, E. G., Dronov, V. V., \& Topuria, L. Y. (2021). Efficiency evaluation of anticoccidials against the background of chickens infection with field coccidia isolate. IOP Conference Series: Earth and Environmental Science, 677(5), 052071.
Yevstafieva, V. O., Kruchynenko, O. V., Mel’nychuk, V. V., Myhajljutenko, S. M., \& Korchan, L. M. (2020). Osoblyvosti poshyrennja parazytoziv ovec u osinn'opasovyshhnyj period [Features of the spread of sheep parasites in the autumngrazing period]. Visnyk Poltavs'koji Derzhavnoji Agrarnoji Akademiji, 4, 163 169 (in Ukrainian). 